\title{
Qualitative Interpretation of Gravity and Aeromagnetic Data in West of Tikrit City and Surroundings, Iraq
}

\author{
Emad Mohammed Salah Al-Heety ${ }^{1 *}$, Mahmoud Abdullah Al-Mufarji², Losyan Habeeb Al Esho ${ }^{3}$ \\ ${ }^{1}$ Department of Applied Geology, University of Anbar, Rammadi, Iraq \\ ${ }^{2}$ Department of Geology, University of Kirkuk, KirKuk, Iraq \\ ${ }^{3}$ Department of Geology, University of Mosul, Mosul, Iraq \\ Email: *salahemad99@gmail.com
}

How to cite this paper: Al-Heety, E.M.S., Al-Mufarji, M.A. and Al Esho, L.H. (2017) Qualitative Interpretation of Gravity and Aeromagnetic Data in West of Tikrit City and Surroundings, Iraq. International Journal of Geosciences, 8, 151-166.

https://doi.org/10.4236/ijg.2017.82005

Received: November 26, 2016

Accepted: February 6, 2017

Published: February 9, 2017

Copyright (C) 2017 by authors and Scientific Research Publishing Inc. This work is licensed under the Creative Commons Attribution International License (CC BY 4.0).

http://creativecommons.org/licenses/by/4.0/

\begin{abstract}
The qualitative interpretation of anomalies of the gravity and the magnetic fields at the west of Tikrit City and surroundings, Iraq, was carried out. According to the tectonic framework of Iraq, the study area is classified as a part of the stable shelf unit. The polynomial technique was employed to separate the residual-regional anomalies as a first step in the qualitative interpretation. Bouguer gravity anomaly map did not exhibit any clear closures. The magnetic maps showed remarkable high closure in the central eastern part of the study area. The regional gravity and magnetic fields values decline towards the eastern parts of the maps (Mesopotamian Basin) in consistent with the increase in the sedimentary cover (basement depth). The residual gravity and magnetic maps displayed several positive and negative closures. The gravity and magnetic lineaments were depicted and superimposed on the tectonic map of the study area. The rose diagram showed that the dominant orientation of the gravity and magnetic lineaments was toward NE-SW.
\end{abstract}

\section{Keywords}

Qualitative Interpretation, Residual Gravity, Residual Magnetic, Gravity Lineaments, Iraq

\section{Introduction}

Gravity and magnetic methods are effectively used in basic geological, geothermal studies and engineering applications [1]. Interpretation of gravity and magnetic data is one of the most proper techniques to find buried traces because they show some significant structural elements which we won't have the capacity to 
take after utilizing morphotectonical tools [2]. The interpretation of gravity and magnetic data may be classified as qualitative and quantitative. Qualitative interpretation of gravity anomalies may be accomplished by analogy to mathematical or experimental surveys over known structures [3]. In some instances, it may be considered as diagnostic. For example, a gravity low located in a favorable geologic province may be indicative of the presence of a salt dome. The qualitative interpretation of magnetic data straightforwardly represents geological information by taking a gander at an aeromagnetic map without any computation [4]. In the qualitative interpretation of gravity and magnetic maps, geophysicists are usually interesting in linear anomalies (Lineaments) as indicator of subsurface faults, contacts, and other tectonic features. Al-Banna [5] used gravity data to contribute to the tectonic evaluation of area next to and to east of the study area. Towfik [6] investigated geophysically and geologically the region located between Baquba and Tikrit. The present work employs the qualitative interpretation of gravity and magnetic anomaly maps of the west of Tikrit and surroundings to: 1) characterize the shapes and patterns of the gravity and magnetic anomalies, and 2) detect the lineaments in both maps. The study area was selected for the lack or scarcity of geophysical studies carried out in spite of its geological and tectonics importance. The findings of the present study contribute to obtaining information on the subsurface geology and evaluating its tectonics. It also emphasizes the importance of qualitative interpretation of Bouguer gravity and magnetic anomalies in determining the structural and/or lithological features that cause those anomalies.

\section{Geologic Setting}

The area of study is located at the west of Tikrit City between latitudes $34^{\circ} 00^{\prime}$ and $35^{\circ} 00^{\prime} \mathrm{N}$ and longitudes $42^{\circ} 00^{\prime}$ and $43^{\circ} 00^{\prime} \mathrm{E}$ (Figure 1). The total area of the

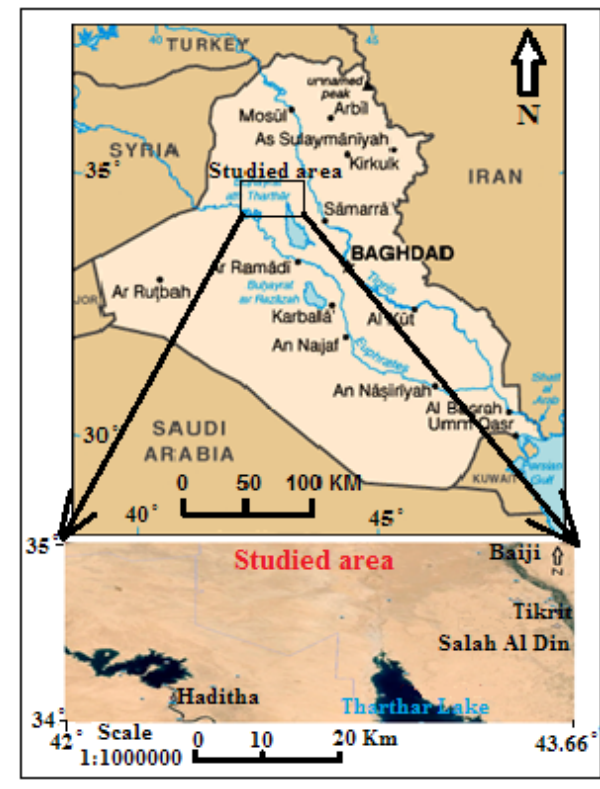

Figure 1. Location map of study area [7]. 
studied area is $18,830 \mathrm{~km}^{2}$. Geomorphologically, the majority of the study area is flat except for the nature of the south-western part and the eastern bank of Lake Tharthar, in which the region is crossed deep valleys and tributaries and lead to a form of hills and barren land. The highest and lowest elevation (above sea level) within the study area is 50 meters 335 meters respectively. The outcropped formations within the study area have ages ranging from Oligocene to Pliocene with the presence of different types of Quaternary deposits (Figure 2). The stratigraphic sequence of the formation in the study area from the oldest to the

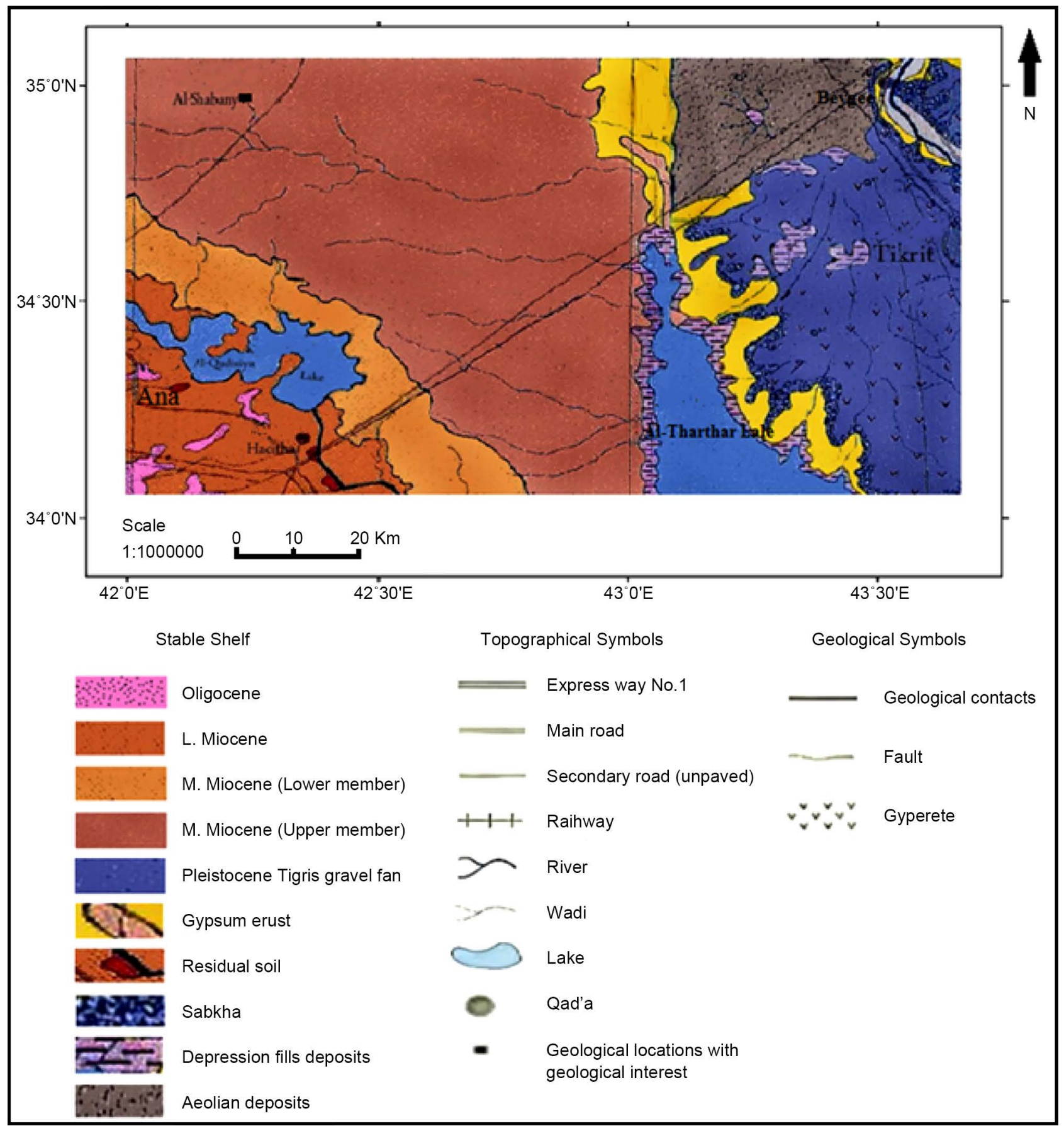

Figure 2. Geologic map of the study area (modified from geologic map of Iraq prepared by [8]). 
youngest is as follows: Anah Limestone Formation (Upper Oligocene), Euphrates Formation (Lower Miocene), Fat'ha Formation or Lower Faris (M. Miocene), Injana Formation or Upper Faris (U. Miocene), Mukdadiya Formation or Lower Bakhtiari (Upper Miocene-Pliocene) and Quaternary Deposits (PleistoceneHolocene). Quaternary deposits include alluvial fans deposits (Pleistocene), gypsum crust (Pleistocene-Holocene), etc.

\section{Tectonic Setting}

Tectonically, the study area locates within the stable shelf (Figure 3 ). The stable shelf covers most of the central south and west of Iraq and extends westwards into Syria and Jordan and southwards into Kuwait and Saudi Arabia. The stable

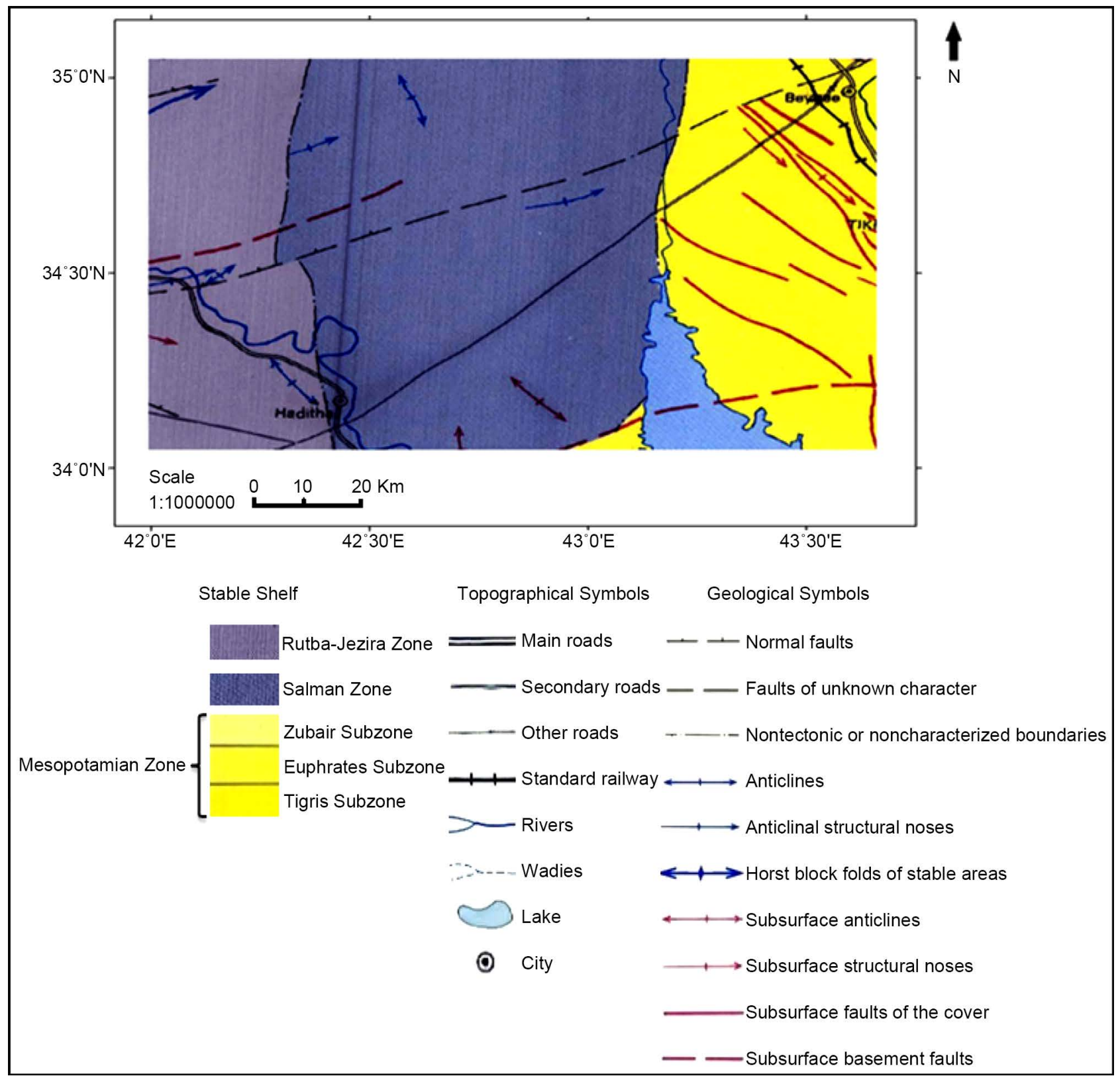

Figure 3. Tectonic map of the study area (modified from tectonic map of Iraq prepared by [9]). 
shelf is a tectonically stable monocline little affected by Late Cretaceous and Tertiary deformation. The orientations of the structures in this tectonic unit were influenced by the geometry of the underlying basement blocks and faults, Palaeozoic epirogenic events and Mesozoic arching [10]. It is divided into three major tectonic zones comprising the Rutba-Jezira zone in the west, the Salman zone, and the Mesopotamian zone in the east [11]:

\subsection{Rutba-Jezira Zone}

The Rutba-Jezira Zone is an inverted Paleozoic basin; the inversion began in the late Permian. The Anah-Qalat Dizeh Fault divides the Rutba-Jezira Zone into more stable Rutba Subzone on the south and the Jezira Subzone in the north. Both subzones contain large basement highs; the Rutbah-Ga'ara high in the south and Deir AlZor-Khlesia high in the north. The unit between the two highs is the Anah Graben. The Rutba Subzone is the most extensive and uplifted part of the Rutba-Jezira Zone. The Rutba Uplift dominated due to inversion of the Paleozoic basin of western Arabia during Latest Permian-Middle Eocene time. The Jezira Subzone was uplifted in Late Miocene-Recent time. It is dominated by the Khlesia basement uplift which is part of the N-S trending Rutba Uplift. The Jezira subzone segmented by two E-W trending grabens; these are the Anah, Tayarat and Khlesia grabens. The Anah graben lies between the Rutba and Jezira subzones. The graben appears narrow at the surface. At it is bounded by a series of E-W trending step faults. Small anticlines occur throughout the subzone. They have been mapped at the level of the Middle Miocene Fatha (Lower Fars) Formation.

\subsection{Salman Zone}

The Salman Zone is part of the Salman-Summan Zone [12] which extends into west Kuwait and Central East Saudi Arabia. The Salman Zone has a shallower basement that Rutba-Jezira Zon to the west and the Mesopotamian Zone of the East. It comprises NE-SW and prominent NW-SE trending uplifts and depressions, bounded by faults. The most conspicuous structures in the Salman Zone strike NW-SE. They are relatively narrow, long anticlines, often accompanied by faults. Other parts of the zone contain relatively short anticlines and structural noses, many of which locate along transversal faults. In the north, these structures trend N-S to NW-SE. The northern part of the zone has fewer faults.

\subsection{Mesopotamian Zone}

The Mesopotamian Zone is the easternmost unit of the Stable Shelf. The zone was probably uplifted during the Hercynian deformation but it subsided from Late Permian time onwards. The Mesopotamian Zone is a relatively flat terrain with a gradient of less than $10 \mathrm{~cm}$ per kilometer extending from Baiji in the NW to the Arabian Gulf in southeast. The Mesopotamian Zone has buried faulted structures below the Quaternary cover, separated by broad synclines. The fold structure mainly trend NW-SE in the eastern part of the zone, an N-S on the 
southern part. The Mesopotamian Zone is divided into three subzones: the Zubair Subzone in the S with N-S trending structures in the south, the Euphrates Subzone in the west, and the Tigris Subzone in the NE with NW-SE trending structure. The Tigris Subzone is the most The Tigris Subzone is the most broad and motile unit of the Mesopotamian Zone. It has broad synclines and narrow anticlines trending predominantly NW-SE, accompanied by long normal faults.

\section{Data Acquisition and Methodology}

The gravity data source of the study area is the Bouguer gravity map of Iraq compiled by [13]. The map has scale of 1:1,000,000 with contour interval of 0.5 mGal. The aeromagnetic map of Iraq carried out by [14] was used to obtain the magnetic data of the study area. The scale and contour interval of the aeromagnetic map are 1:1,000,000 and 5 Gamma, respectively. The original Bouguer gravity and magnetic maps of the investigated area are shown in (Figure 4 and Figure 5). The measured gravity and magnetic fields consist of the superposition of anomalies from a variety of sources. They include: 1) the so-called residual anomalies, which are the anomalies of particular interest in a study, 2) the longer-wavelength regional components derived largely from deep, large-volume geologic sources, and 3) the shorter-wavelength noise due to observational and data reduction errors and small, shallow sources [15]. The process of removal of

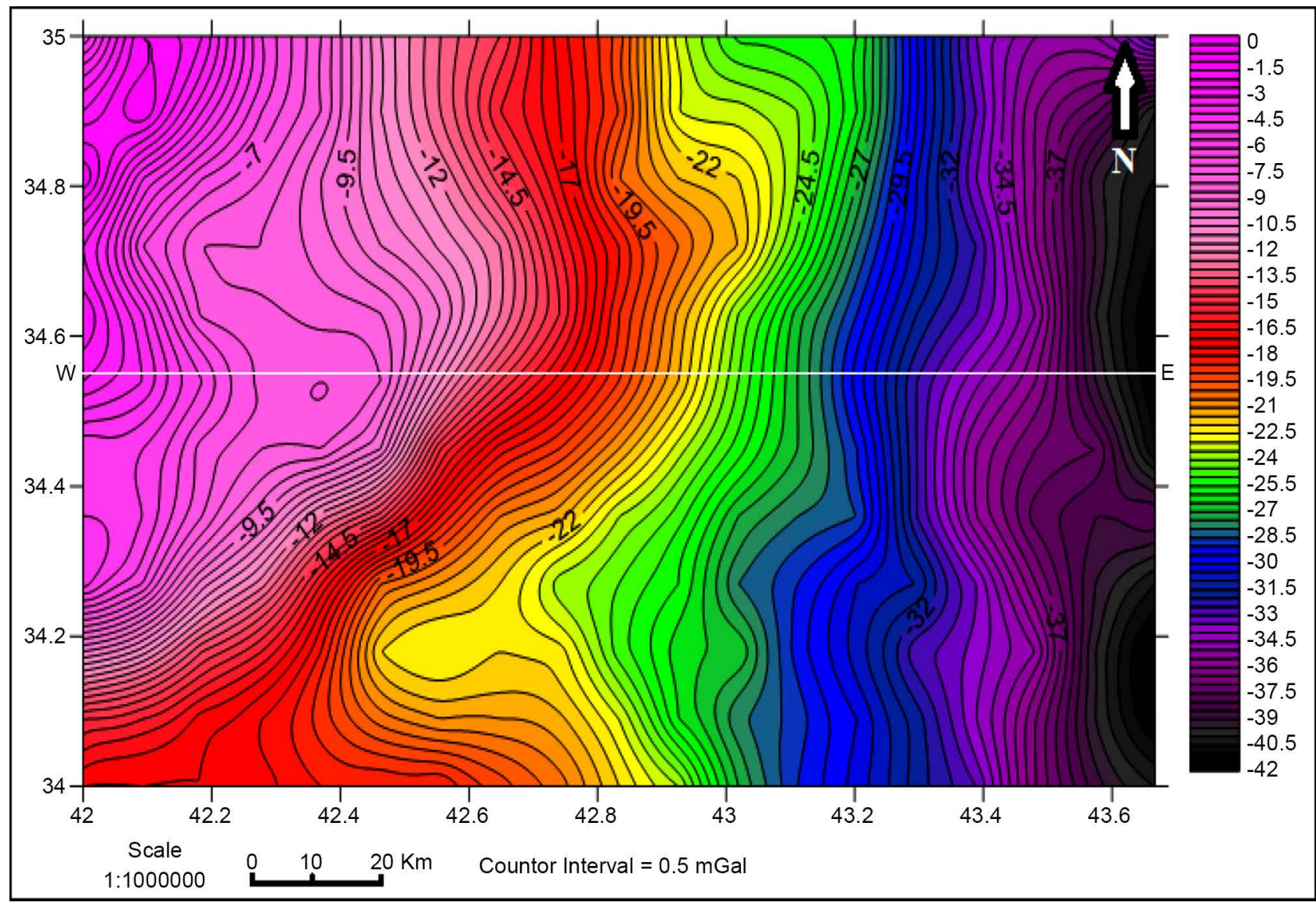

Figure 4. Gravity Bouguer anomaly map of the study area (after [13]). 


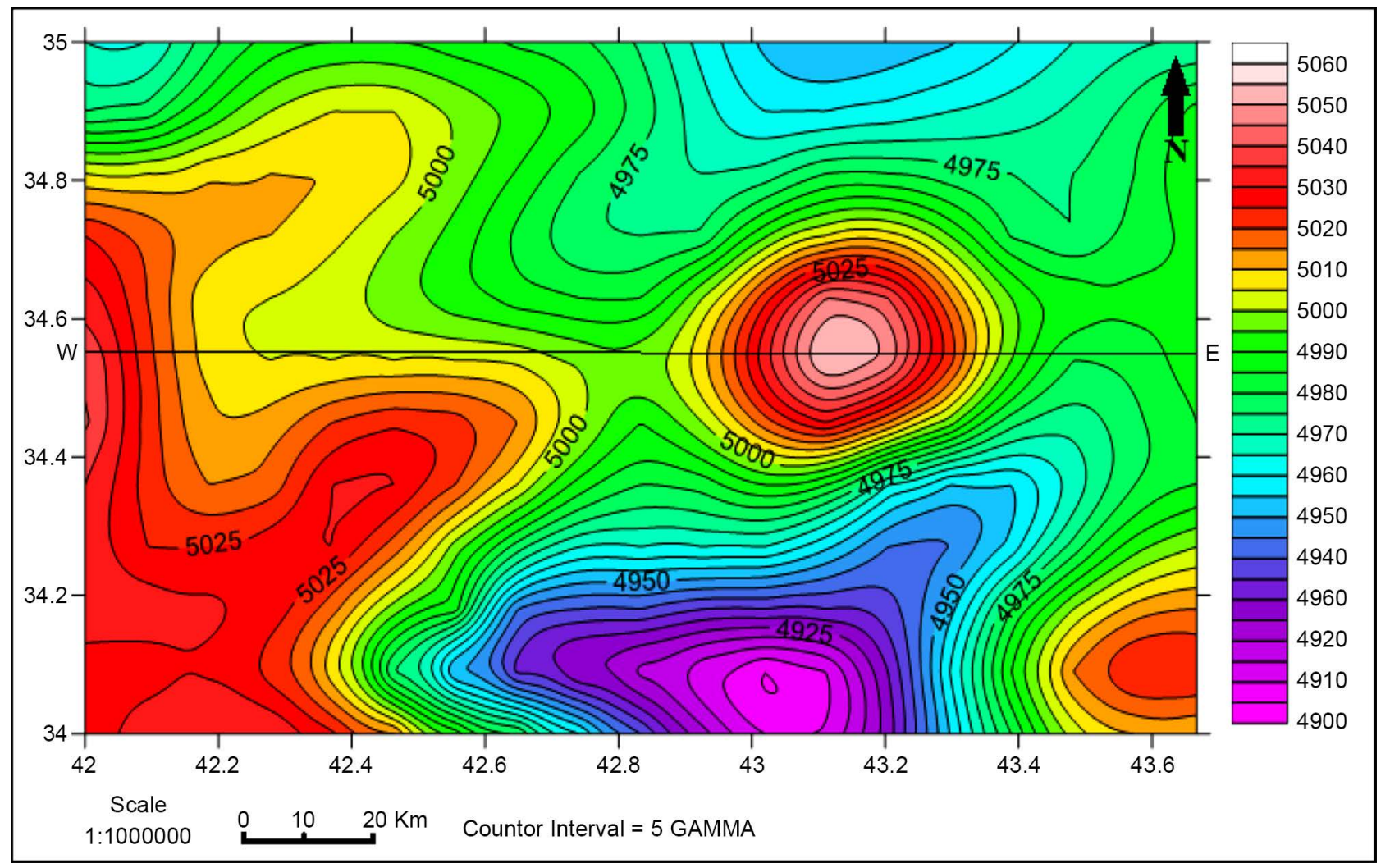

Figure 5. Aeromagnetic map of the study area (after [14]).

the interfering regional and noise components in the anomaly field is the residual-regional problem which is one of the critical steps in anomaly interpretation. It is solved by either isolating the residual anomaly through elimination or attenuation of the regional and noise anomalies or enhancing the residual relative to the interfering effects. The isolation and enhancement of gravity and magnetic anomalies is a filtering process in which only the spatial wavelengths of interest are passed and the remainder are eliminated or at least highly attenuated. Residual anomaly separation may be based on a variety of anomaly attributes such as magnitude, shape, sharpness or gradients, orientation, and correlation with other data. The residual-regional separation is the critical problem in gravity and magnetic anomaly interpretation [15]. There are a number of methods can be applied to isolate the residual anomaly from the regional anomaly were reviewed by a number of investigators (e.g. [15] [16] [17]. In this study, polynomial method was employed for residual-regional separation. This method represents the residual-regional anomalies as least squares polynomial approximations or trend surfaces [18] [19]. Trend surface analysis is one of the most flexible analytical techniques for separating regional anomaly from residual anomaly [20]. Trend surface analysis involves fitting a surface to the data through use of a polynomial series, normally of low order. The selected surface is considered to be the regional field. The residual anomaly is estimated by subtraction the regional anomaly values from the observed anomaly values. The polynomial method was employed in many studies (e.g. [16] [17] [21]-[27]. Polynomial fit- 
ting can be applied in local and regional surveys with high-resolution results [16] [25] [26]. As a first step of the qualitative interpretation, a residual-regional isolation was performed analytically.

\section{Results and Discussion}

\subsection{Bouguer Anomaly Map}

The visual inspection of the Bouguer anomaly map (Figure 4) shows a linear trend elongated in SW-NE and NW-SE directions at the central western parts of the studied area. The clear feature is decreasing of Bouguer values towards the eastern parts of the map. This remarkable feature may show increasing of sedimentary cover thickness or basement depth. Basement depths range from $7 \mathrm{~km}$ in the south to $10 \mathrm{~km}$ in the north of the Jizera area that occupies the western parts of the study area. Basement depth in the Salman zone (central parts of the study area) is mostly $6-7 \mathrm{~km}$; along the boundary with the Mesopotamian Zone (the eastern parts of the study area) the basement depth increases to $8-9 \mathrm{~km}$ [28]. The basement depth in the Mesopotamian zone increases to $13 \mathrm{~km}$. Bouguer gravity values decline gradually as the basin deepens. The gradual decrease in Bouguer values indicates a gradual increase in the crustal thickness [29]. The seismological and gravity studies have been carried out in Iraq showed that the crustal thickness in Iraq increases from the western parts (Iraqi-Jordanian and Syrian borders) towards the eastern parts (Iraqi-Iranian borders) [30] [31]. Generally, the gravity anomaly field of the study area is not complex. The complexity of the gravity anomaly field can be indicator of crustal instability. The study area is classified as a part of the Stable Shelf that is a tectonically stable monocline little affected by late Cretaceous and Tertiary deformation [28]. The stability of the study area may be affected in the little relative simplicity of the gravity anomaly field of it. In general, the Bouguer anomaly map of the investigated area shows high gravity gradient zones in the western parts relative to the eastern parts. The horizontal gradient maxima (highs) values are indicative of lateral density contrasts. These density contrasts can be interpreted in terms of geological contacts or structural accidents. The Bouguer anomaly map of any area is a continuation of gravity effects of the various litho-stratigraphic units composing the sedimentary cover as well as that of the basement complex [32].

\subsection{Regional and Residual Gravity Anomaly Maps}

The regional and residual gravity anomaly maps of the study area are shown in (Figure 6). The regional map obtained with the polynomial method presents linear contour in NE-SW direction (Figure 6(a)). The regional gravity values decrease towards $\mathrm{E}$, from -4 to $-40 \mathrm{mGal}$. The residual anomaly map (Figure $6(\mathrm{~b}))$ showed that the residual values range from -8.5 to $5.5 \mathrm{mGal}$. The residual map revealed several positive and negative closures. These anomalies reflect the lateral variation of density in the basement related to geological structure. The main positive anomaly is trending in NE-SW. The maximum value of this positive anomaly is greater than $5 \mathrm{mGal}$. The main negative anomaly has direction of 


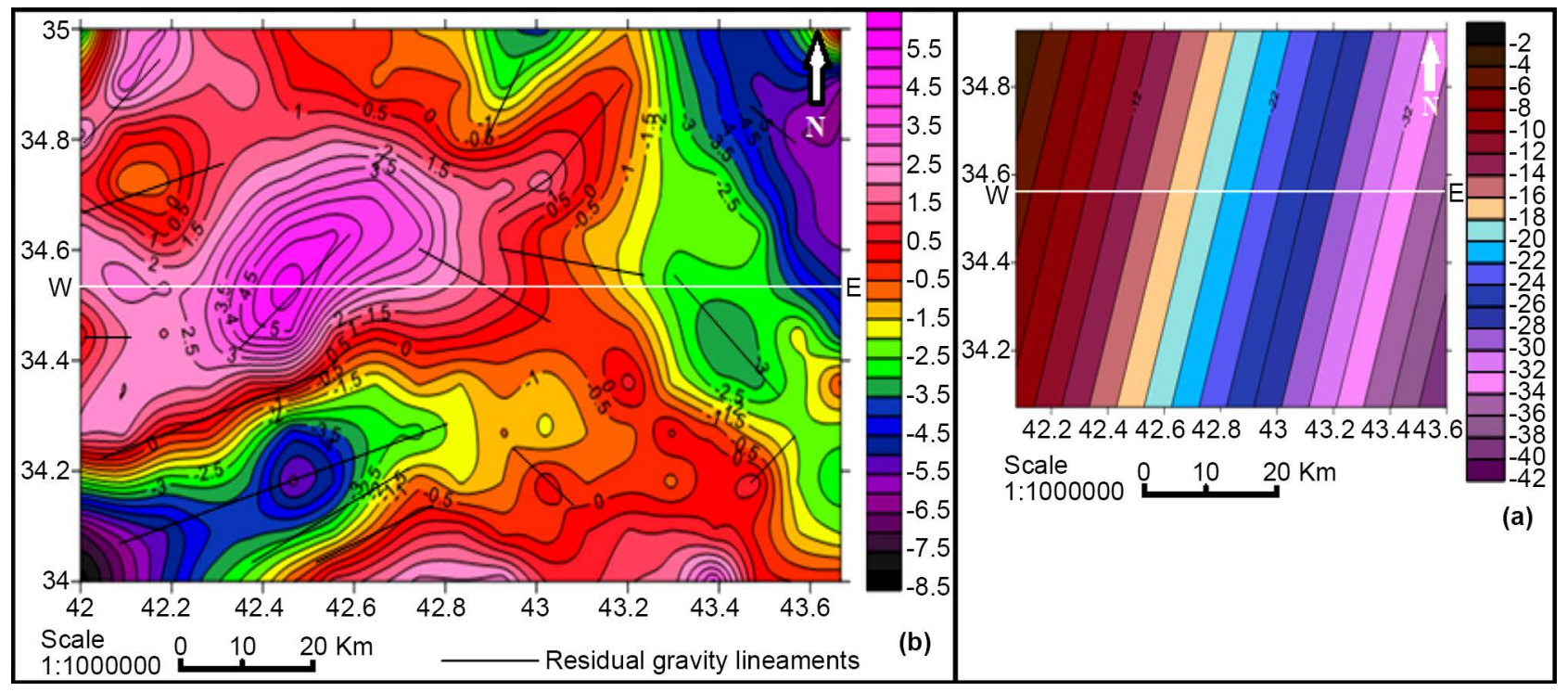

Figure 6. (a) Regional gravity anomaly map, (b) Residual gravity anomaly map including the lineaments.

$\mathrm{NW}$-SE with the maximum value less than $-5.5 \mathrm{mGal}$. Many linear features that have different trends appear at the residual map. The profiles of Bouguer, regional and residual anomalies along E-W trend were plotted (Figure 7). The all profiles showed decreasing of the gravitational acceleration towards the eastern parts of the study area. There is coincidence between Bouguer gravity and regional gravity trends. This coincidence may be interpreted in term of common deep source (basement and/or crustal structure) and this deep source contributes the most amount of the Bouguer gravity field of the study area compared with the contribution of the shallow source.

\subsection{Aeromagnetic Map}

Qualitatively, the aeromagnetic map of the study area (Figure 5) shows that the magnetic values range from 4905 to $5055 \mathrm{Gamma}$. The map reveals that the main high magnetic anomaly has a NE-SW trend with the amplitude of 55 Gamm and its dimensions are $84 \mathrm{~km}$ in length and $49 \mathrm{~km}$ in width. High magnetic nose with maximum value of 5025 Gamma with E-W trend appears in the southeastern part of the map. Low magnetic anomaly with an amplitude of 4905 Gamma and NW-SE trend appears to the south of the main high anomaly. There are a number of low and high magnetic noses with trends of NE-SW and different magnetic amplitudes. The magnetic gradient shows low values in the central western parts and high in the southern parts of the study area. The configuration of high magnetic anomalies may be attributed to basement structure and composition.

\subsection{Regional and Residual Magnetic Anomaly Maps}

The regional magnetic anomaly map reveals that the regional values range from 4915 to 5055 Gamma (Figure 8(a)). The residual magnetic anomaly map (Figure $8(\mathrm{~b})$ ) showed several positive and negative magnetic anomalies. The residual 

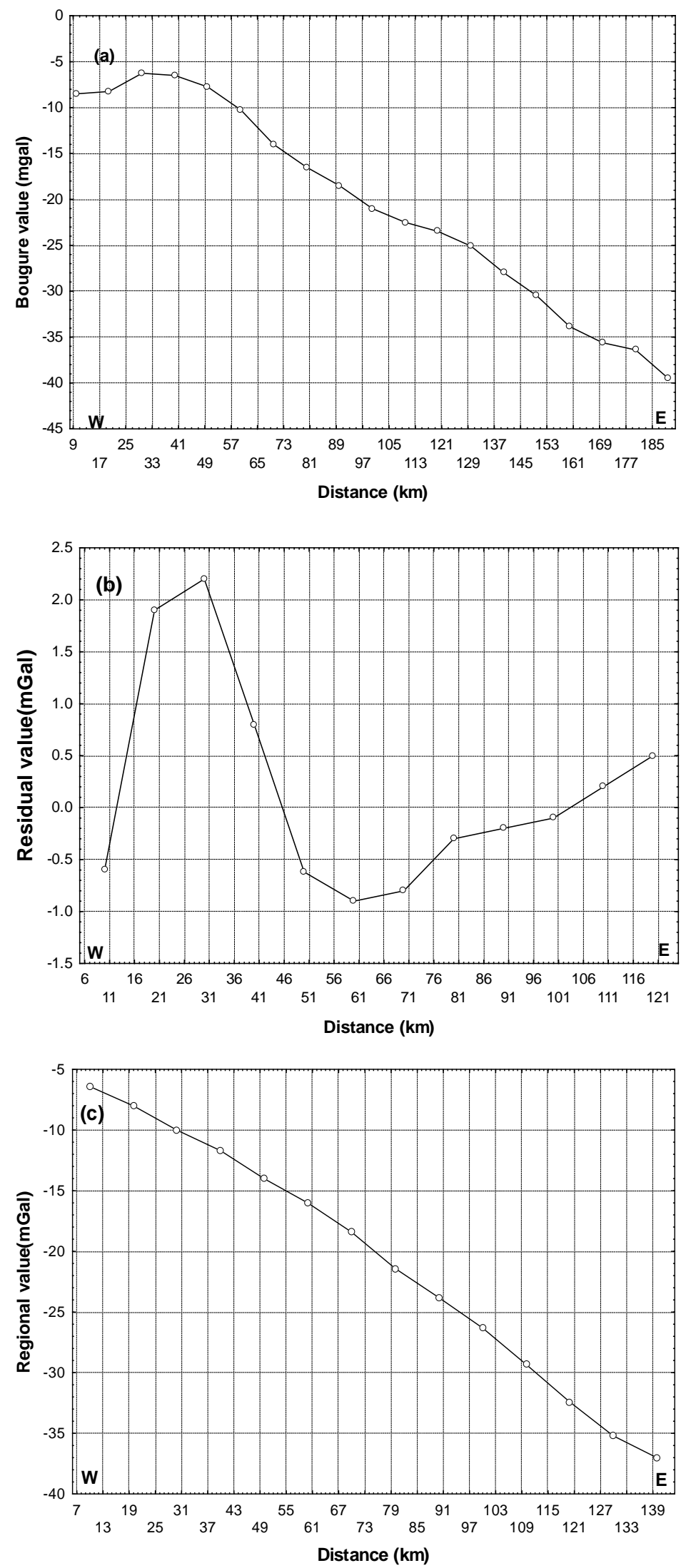

Figure 7. (a) Gravity Bouguer anomaly profile, (b) Gravity residual anomaly profile, (c) Gravity regional anomaly map. 


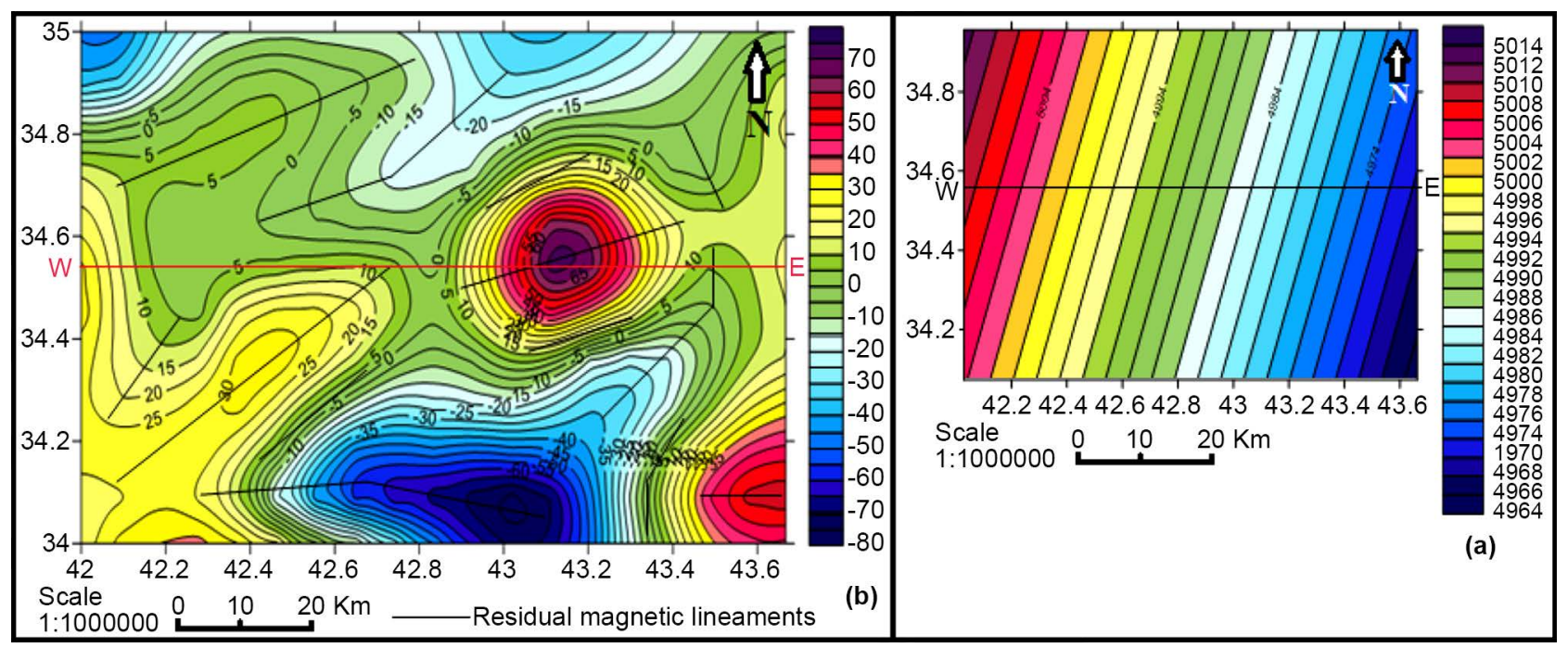

Figure 8. (a) Regional magnetic anomaly map, (b) Residual magnetic anomaly map including the lineaments.

values range from -30 to $45 \mathrm{Gamma}$. The map reveals main positive anomaly of NE-SW trend with amplitude, of 40 Gamma. There are positive and negative magnetic noses with trend of NE-SW. There is a clear matching between the magnetic field and residual magnetic field (Figure 9). This may reflect the fact that the source of the magnetic field of the study area is shallow and contributes the major percentage of the magnetic field compared to the deep sources. The regional trend is not in coincidence with trend of the original aeromagnetic map (Figure 9). The regional magnetic trend is in coincidence with the regional gravity trend and both decline towards the eastern parts of the study area confirming increasing of basement depth in this direction. This result means that the basement structure and/or composition may be the source of the regional gravity and regional magnetic anomaly.

\subsection{Gravity and Magnetic Lineaments Analysis}

The gravity and magnetic lineaments were detected from the original Bouguer gravity anomaly and the original aeromagnetic maps. The basic features used to delineate the linear features in the gravity and magnetic maps are the abrupt changes in orientation of the contours or close spacing of the contours [33] [34] and locations of horizontal gradients and anomaly boundaries [16] [35] [36] [37]. Steep, straight faults are commonly expressed as subtle potential field lineaments, which can be gradients zones, alignments of separate local anomalies of various types and shapes aligned breaks or discontinuities in the anomaly pattern. Horizontal gradient maxima occur over the steepest parts of potential field anomalies and minima over flattest parts. Horizontal gradient maxima highlight areas with abrupt change in density, interpreted either faults or geologic contact, as intrusive information [38] [39]. Trends analysis of lineaments deduced from the residual gravity and magnetic maps and their rose diagrams are given in (Figure 10). The rose diagrams showed that the trend of majority of gravity and magnetic lineaments is toward NE-SW. To compare the gravity and magnetic 

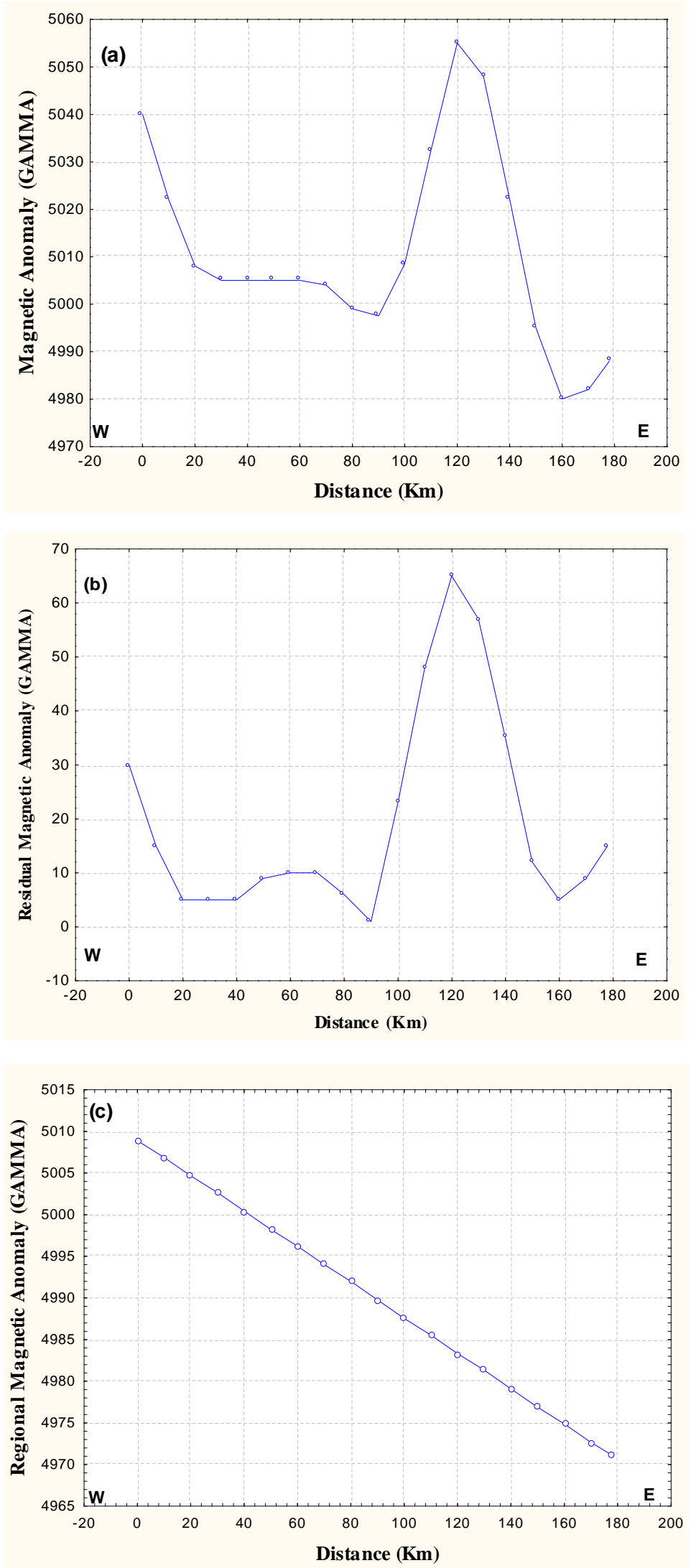

Figure 9. (a) Magnetic anomaly profile, (b) Magnetic residual anomaly profile, (c) Magnetic regional anomaly profile. 

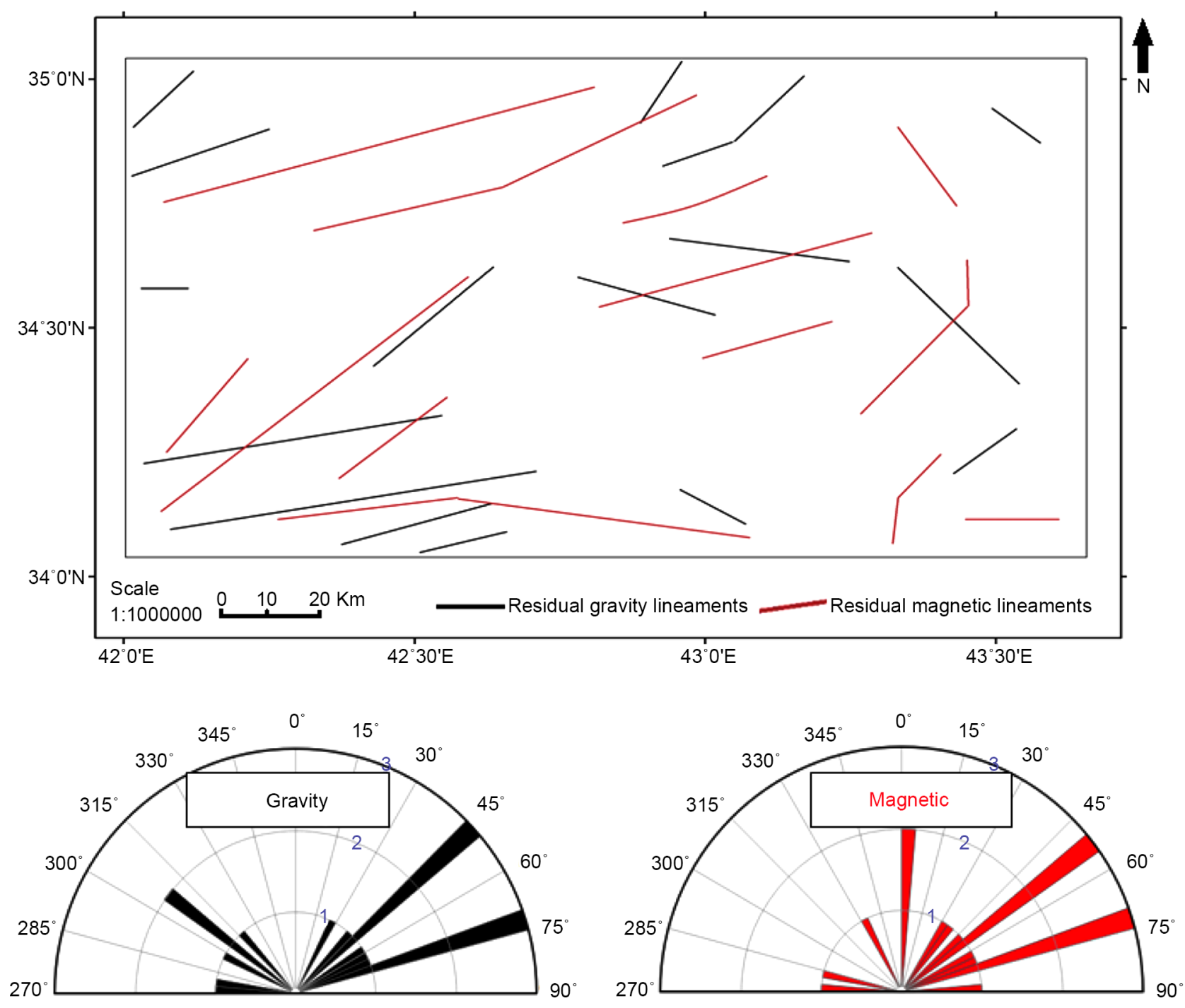

Figure 10. Residual gravity and magnetic lineaments map. Rose diagrams of lineaments.

lineaments with the structural and tectonic features of the study area, they are superimposed on its tectonic map (Figure 11). Generally, the orientation of gravity and magnetic lineaments is in coincidence with that of the structural elements in the study area.

\section{Conclusions}

According to the results of the current study, we drew up the following conclusions:

1) The little relative simplicity of the Bouguer anomaly map may be controlled by stability of the study area.

2) The gradual decreasing of Bouguer gravity values towards the eastern parts of study area indicates a gradual increase in thickness of the crust beneath it.

3) The coincidence of the Bouguer gravity trend with the regional gravity trend may be attributed to the common deep source which subscribes the largest amount of the Bouguer gravity field of the study area. 


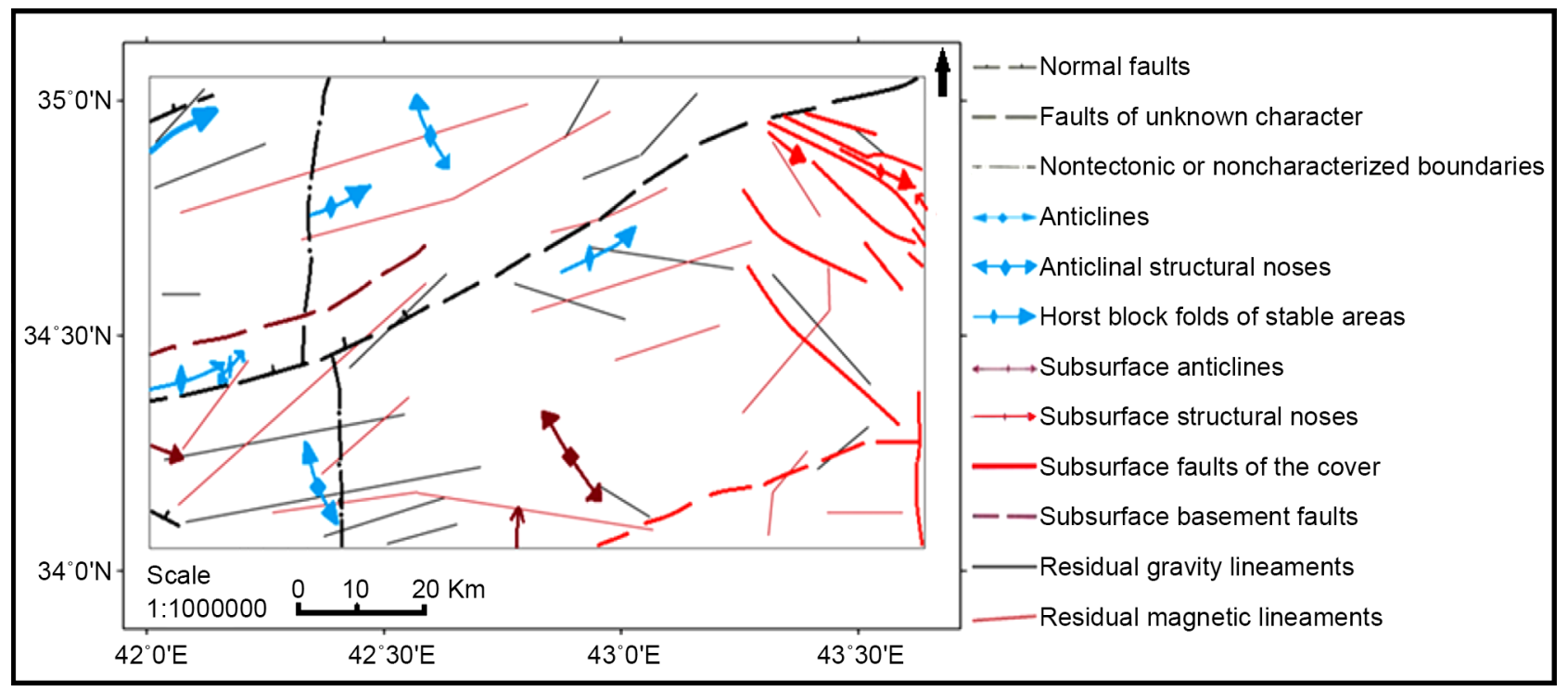

Figure 11. Gravity and magnetic lineaments superimposed on the tectonic map of the study area.

4) The horizontal gradient maxima in the western parts of the study area are indicative of lateral density contrasts.

5) The matching of the magnetic field with the residual magnetic field may be interpreted in terms of a shallow source which contributes the major quantity of the magnetic field of the study area.

6) The orientation of majority of the residual gravity and magnetic lineaments is toward NE-SW. In general, the orientation of gravity and magnetic lineaments is in coincidence with that of the structural elements in the study area.

\section{Acknowledgements}

The authors thank the Iraqi Geological Survey (GEOSURV) for providing the geologic, tectonic, Bouguer gravity and Aeromagnetic maps used in the study. Special thanks to Dr. Abbas Yass for his supporting and help. We appreciate Prof. Dr. Ahmed Al-Banna from Department of Earth Science, University of Baghdad for his constructive comments.

\section{References}

[1] Aydogan, D., Pinar, A., Elmas, A., Tarhan Bal, O. and Yuksel, S. (2013) Imaging of Subsurface Lineaments in the Southwestern Part of Thrace Basin from Gravity Data. Earth Planets Space, 65, 299-309. https://doi.org/10.5047/eps.2012.08.014

[2] Aryamanesh, M. (2014) Estimating the Hidden Gravity Lineaments Depths by Using Special Function Method and Comparing Them with the Earthquake Focal Depths: A Case Study of Gujarat Province. Geodynamics Research International Bulletin, 1, 55-61.

[3] Mccollum, E.V. (1944) The Interpretation of Gravity Anomaly. Tusla Geological Society Digest, 13, 53-54.

[4] Grant, F.S. and West, G.E. (1965) Interpretation Theory in Applied Geophysics. McGraw-Hill, New York.

[5] Al-Banna, A.S. (1998) Contribution to the Tectonic Evaluation of Hamrin-Samarra- 
Tikrit Area Using Gravity Data. Iraqi Geological Journal, 31, 1-12.

[6] Towfik, A.N. (1992) Geological and Geophysical Study of Tikrit-Baquba Region. Iraqi Geological Journal, 25, 1-17. (In Arabic)

[7] http://alwaght.com/upload/files/2016102443/20161024181152252.png

[8] GEOSURV (Iraqi Geological Survey) (1993) Geologic Map of Iraq.

[9] GEOSURV (Iraqi Geological Survey) (1987) Tectonic Map of Iraq.

[10] Jassim, S.Z. and Buday, T. (2006) Tectonic Framework. In: Jassim, S.Z. and Goff, J.C., Eds., Geology of Iraq, Dolin, Prague, 35-52.

[11] Jassim, S.Z. and Buday, T. (2006) Units of the Stable Shelf. In: Jassim, S.Z. and Goff, J.C., Eds., Geology of Iraq, Dolin, Prague, 53-72.

[12] Getech and Jassim, S.Z. (2002) The Basin Development of Arabia. GETECH, School of Earth Sciences, University of Leeds, Leeds, Report No. Go227, 414 p.

[13] Abbas, M.J., Al-Kadhimi, J. and Fattah, A.S. (1984) Unified Gravity Map of Iraq. SEGMI, Internal Report, Baghdad.

[14] Compagnie Generale de Geophysique (CGG) (1974) Aeromagnetic and Aerospectrometric Survey. Interpretation Report, SOM, Unpublished.

[15] Hinze, W.J., von Frese, R.R. and Saad, A.H. (2012) Gravity and Magnetic Exploration: Principle, Practices, and Applications. Cambridge University Press, Cambridge, $530 \mathrm{p}$.

[16] Martinez-Moreno, F.J., Galindo-Zaldivar, J., Pedrera, A., Teixido, T., Peňa J.A. and González-Castillo, L. (2015) Regional and Residual Anomaly Separation in Microgravity Maps for Cave Detection: The Case Study of Gruta de las Maravillas (SW Spain). Journal of Applied Geophysics, 114, 1-11. https://doi.org/10.1016/j.jappgeo.2015.01.001

[17] Al-Rahim, A. (2016) Separating the Gravity Field of Iraq by Using Bidimensional Empirical Mode Decomposition Technique. Arabian Journal of Geosciences, 9, 43. https://doi.org/10.1007/s12517-015-2118-7

[18] Coons, R.L., Woollard, G.P. and Hershey, G. (1967) Structural Significance and Analysis of Mid-Continent Gravity High. American Association of Petroleum Geologists Bulletin, 51, 2381-2399.

[19] Steenland, N.C. (1968) Structural Significance and Analysis of Mid-Continent Gravity High: Discussion. American Association of Petroleum Geologists Bulletin, 52, 2263-2267.

[20] Krumbein, W.C. (1966) A Comparison of Polynomial and Fourier Models in Map Analysis. Technical Report No. 2 of ONR Task No. 388-1228. Dep. Of Geology, Northwestern Univ. Evanston, Evanston.

[21] Agarwal, B.N.P. and Sivaji, C.H. (1992) Separation of Regional and Residual Anomalies by Least Squares Orthogonal Polynomial and Relaxation Techniques: A Performance Evaluation. Geophysical Prospecting, 40, 143-156. https://doi.org/10.1111/j.1365-2478.1992.tb00368.x

[22] Al-Rawi, F.R., Ali, S.K. and Hassan, I.A. (1992) Regional Gravity and Aeromagnetic Anomalies across Iraq Territory and Their Relation to Crustal Layer. Iraqi Geological Journal, 25, 105-119.

[23] Camacho, A.G., Vieira, R., Montesinos F.G. and Cuéllar, V. (1994) A Gravimetric 3D Global Inversion for Cavity Detection. Geophysical Prospecting, 42, 113-130. https://doi.org/10.1111/j.1365-2478.1994.tb00201.x

[24] Ojo, S.B. and Kangkolo, R. (1997) Shortcomings in the Determination of Regional Fields by Polynomial Fitting: A Simple Solution. Journal of Applied Geophysics, 36, 
205-212. https://doi.org/10.1016/S0926-9851(96)00043-2

[25] Sedighi, M., Tabatabaee, S. and Najafi-Alamdari, M. (2009) Comparison of Different Gravity Field Implied Density Models of the Topography. Acta Geophysica, 57, 257-270. https://doi.org/10.2478/s11600-008-0069-Z

[26] Martín, A., Nñúez, M.A., Gili, J.A. and Anquela, A.B. (2011) A Comparison of Robust Polynomial Fitting, Global Geopotential Model and Spectral Analysis for Regional-Residual Gravity Field Separation in the Doñana National Park (Spain). Journal of Applied Geophysics, 75, 327-337. https://doi.org/10.1016/j.jappgeo.2011.06.037

[27] Al-Zoubi, A., Eppelbaum, L., Abueladas, A., Ezersky, M. and Akkawi, E. (2013) Removing Regional Trends in Microgravity in Complex Environments: Testing on 3D Model and Field Investigations in the Eastern Dead Sea Coast (Jordan). International Journal of Geophysics, 2013, Article ID: 341797. https://doi.org/10.1155/2013/341797

[28] Goff, J.C. and Jassim, S.Z. (2006) Geology of Iraq. Dolin, Prague, 486 p.

[29] Choi, K.S., Kumar G.V.R. and Kim, K.Y. (1999) Qualitative Interpretation of Bouguer Anomaly in the Southern Part of the Korean Peninsula. Geosciences Journal, 3, 4954. https://doi.org/10.1007/BF02910234

[30] Al-Banna, A.S. and Al-Heety, E.A. (1996) Crustal Thickness Map of Iraq Deduced from Gravity Data. Iraqi Journal of Science, 35, 749-765.

[31] Al-Heety, E.A. (2002) Crustal Structure of the Northern Arabian Platform Inferred Using Spectral Ratio Method. Journal of Geodynamics, 34, 63-75. https://doi.org/10.1016/S0264-3707(02)00017-0

[32] Senosy, M.M., Youssef, M.M. and Abdel Zaher, M. (2013) Sedimentary Cover in the South Western Desert of Egypt as Deduced from Bouguer Gravity and Drill-Hole Data. Journal of African Earth Sciences, 82, 1-14. https://doi.org/10.1016/j.jafrearsci.2013.02.001

[33] Onuba, L.N., Anudu, G.K., Chiaghanam, O.I. and Anakwuba, E.K. (2011) Evaluation of Aeromagnetic Anomalies over Okigwe Area, Southeastern Nigeria. Research Journal of Environment and Earth Sciences, 3, 498-507.

[34] Karnieli, A., Meisels, A., Fisher, L. and Arkin, Y. (1996) Automatic Extraction and Evaluation of Geological Linear Features From Digital Remote Sensing Data Using a Hough Transform. Photogrammetric Engineering \& Remote Sensing, 62, 325-531.

[35] Lyngsie, S.H., Thybo, H. and Rasmussen, T.M. (2006) Regional Geological and Tectonic Structures of the North Sea Area from Potential Field Modeling. Tectonophysics, 413, 147-170. https://doi.org/10.1016/j.tecto.2005.10.045

[36] Ayogan, D. and Komazawa, M. (2013) Lineament Detection from Gravity Anomaly Maps with the Gradient Hough Algorithm in Adapazari Basin. http://muhendislike.Istanbul.edu.tr/jeobji/wp-content/uploads/2014

[37] Cordell, L. and Grauch, V.J.S. (1985) Mapping Basement Magnetization Zones from Aeromagnetic Data in the San Juan Basin, New Mexico. In: Hinze, W.J., Ed., The Utility of Regional Gravity and Magnetic Anomaly Maps, Society of Exploration Geophysicists, 181-197. https://doi.org/10.1190/1.0931830346.ch16

[38] Shandini, Y. and Tadjou, J.M. (2012) Interpreting Gravity Anomalies in South Cameroon, Central Africa. Earth Sciences Research Journal, 16, 5-9.

[39] Claude, N.P., Clotilde, O.A., Marcelin, B.B., Antoine, W.K., Igor, O.A. and Théophile, N.M. (2016) Evidence by Multi-Scale Analysis of Lineaments Derived from Gravity Anomalies in the Batouri Area (Eastern-Cameroon). International Journal of Science and Research, 5, 866-874. 
Submit or recommend next manuscript to SCIRP and we will provide best service for you:

Accepting pre-submission inquiries through Email, Facebook, LinkedIn, Twitter, etc. A wide selection of journals (inclusive of 9 subjects, more than 200 journals)

Providing 24-hour high-quality service

User-friendly online submission system

Fair and swift peer-review system

Efficient typesetting and proofreading procedure

Display of the result of downloads and visits, as well as the number of cited articles Maximum dissemination of your research work

Submit your manuscript at: http://papersubmission.scirp.org/

Or contact ijg@scirp.org 